CARRA, César Augusto. Considerações sobre a constitucionalidade da contribuição sindical compulsória. Revista Eletrônica Direito e Política, Programa de Pós-Graduação Stricto Sensu em Ciência Jurídica da UNIVALI, Itajaí, v.10, n.2, $1^{0}$ quadrimestre de 2015. Disponível em: www.univali.br/direitoepolitica - ISSN 1980-7791.

\title{
CONSIDERAÇÕES SOBRE A CONSTITUCIONALIDADE DA CONTRIBUIÇÃO SINDICAL COMPULSÓRIA
}

\author{
CONSIDERATIONS ABOUT THE CONSTITUTIONALITY OF THE \\ COMPULSORY UNION CONTRIBUTION
}

César Augusto Carra ${ }^{1}$

SUMÁRIO: Introdução; 1. Âmbito Dogmático do Artigo; 2. Origem e Considerações sobre a Contribuição Sindical Compulsória; 3. Da Natureza Jurídica da Contribuição Sindical; 4. Da Inconstitucionalidade Formal da Contribuição Sindical Compulsória; Considerações Finais; Referências das Fontes Citadas.

RESUMO: Este artigo, valendo-se da metodologia dedutiva, tece algumas considerações sobre a constitucionalidade formal da contribuição sindical (imposto sindical). Comentando sobre a instituição da exação, e baseando-se numa interpretação histórica e progressiva, após mencionar precedente do Pretório Excelso quanto à recepção da contribuição pela atual Constituição, demonstrará que, ainda que certa tal conclusão sob a perspectiva material, na formal, a asserção é diversa. Citando a proibição dos arts. 13, d e 49 da Carta de 1937, e que a contribuição sindical deve ser aferida com base no tempus regit actum, valendo-se da orientação firmada pelo STF quanto ao parâmetro no controle de constitucionalidade difuso, demonstrará que, contrariando os preceitos, a contribuição sindical não poderia subsistir. Obstrutiva da recepção, e não se prestando, o poder constituinte originário, a convalidar diplomas nulos, a contribuição sindical compulsória deve ser considerada como revogada pela nova Constituição, sendo ilegítima a sua cobrança.

\footnotetext{
${ }^{1}$ Graduado em Direito pelo Centro Universitário de Bauru (2011), mantido pela Instituição Toledo de Ensino. Mestrando da Instituição Toledo de Ensino, no programa de Pós-graduação em Direito, área de concentração Sistema Constitucional de Garantia de Direitos, com atuação na linha de pesquisa Acesso à Justiça e Concretização de Direitos. Pós-graduando no programa de Pósgraduação lato sensu em Direito Empresarial (GV Law) pela Fundação Getúlio Vargas. Pósgraduando no programa de Pós-graduação lato sensu em Direito Municipal pela Escola Paulista de Direito. Bariri. Estado de São Paulo. Brasil. Procurador Legislativo da Câmara Municipal de Itápolis. E-mail: cescarra@live.com.
} 
CARRA, César Augusto. Considerações sobre a constitucionalidade da contribuição sindical compulsória. Revista Eletrônica Direito e Política, Programa de Pós-Graduação Stricto Sensu em Ciência Jurídica da UNIVALI, Itajaí, v.10, n.2, $1^{0}$ quadrimestre de 2015. Disponível em: www.univali.br/direitoepolitica - ISSN 1980-7791.

Palavras-chave: Contribuição Sindical; Constituição de 1937; Inconstitucionalidade formal; Recepção.

ABSTRACT: This article, drawing upon the deductive methodology, presents some considerations about the formal constitutionality of union contribution (tax dues). Commenting on the establishment of the exaction, and based on a historical and progressive interpretation, after previous mention the Pretório Excelso as the receipt of the contribution by the current Constitution, demonstrate that even if such a conclusion under a material view, the formal perspective, the assertion is diverse. Citing the prohibition of arts. $13, d$ and 49 of the 1937 Letter and the union dues should be measured based on regit actum tempus, drawing upon the guidance signed by the STF as the parameter in the control of diffuse constitutionality, will demonstrate that, contrary to the precepts, the contribution union could not stand. Obstructive reception, and not paying, the original constituent power, to validate zero degrees, compulsory union contribution should be considered repealed by the new Constitution, being illegitimate their collection.

Keywords: Union Contribution; Constitution of 1937; Formal unconstitutionality; Reception.

\section{INTRODUÇÃO}

Muitas foram as discussões travadas quanto à constitucionalidade, ou não, da contribuição sindical compulsória. Analisando-a, na maioria das vezes, sob a perspectiva da Constituição atual, doutrina e jurisprudência, fronte ao estipulado nos arts. $8^{\circ}, \mathrm{V}$ e 149 , caput, tenderam a reconhecer sua constitucionalidade, admitindo a validade da exação.

Prova maior disso é o precedente formado pelo Supremo Tribunal Federal que, acolhendo proposta do eminente relator, Ministro Sepúlveda Pertence, decidindo o RE 180.745/SP, acabou assentando a recepção da aludida contribuição sindical.

Malgrado aquele entendimento, e resguardada a autoridade dos fundamentos que Ihe dão suporte, através de um estudo sob a compatibilidade formal, podese entrever que existem argumentos capazes de infirmar aquela orientação predominante. 
CARRA, César Augusto. Considerações sobre a constitucionalidade da contribuição sindical compulsória. Revista Eletrônica Direito e Política, Programa de Pós-Graduação Stricto Sensu em Ciência Jurídica da UNIVALI, Itajaí, v.10, n.2, $1^{0}$ quadrimestre de 2015. Disponível em: www.univali.br/direitoepolitica - ISSN 1980-7791.

Alterando o prisma de enfrentamento, e averiguando a constitucionalidade da contribuição sindical, denominada, até 1966, imposto sindical, sob o ponto de vista formal, tentar-se-á evidenciar que sendo dotada de alta carga tributária, constituindo verdadeiro tributo, a validade da figura oriunda do Estado Novo tem condições de ser questionada frente ao expressado na Constituição dos Estados Unidos do Brasil, de 1937.

Impondo limitações materiais à edição de decretos-leis por parte do Presidente da República, mormente quando veiculassem matéria tributária, e inserindo-se o diploma instituidor da malfadada contribuição nessa situação, à luz dos arts. 13, d e 49 da ab-rogada Carta Constitucional, apercebe-se possível mácula no processo de formação da norma, vindo a acarretar, assim, sua inconstitucionalidade formal.

Ora, importando na nulificação do diploma $a b$ initio, devendo a inconstitucionalidade formal, quando exercida no controle incidente, ser aferida segundo o texto constitucional vigente à época de sua edição, e não se propondo, o poder constituinte originário, dentro de sua própria grandeza, a restabelecer diplomas nulos, caso constatado que, de fato, a contribuição sindical compulsória desobedeceu ao processo para sua formação, consequência inarredável será sua não recepção por parte da atual Constituição da República, ainda que compatível com esta sob o prisma material.

Nessa linha de entendimento é que, valendo-se do método dedutivo, e da lógica da argumentação, buscar-se-á traçar um paralelo, a fim de, cientificamente, tentar justificar a inconstitucionalidade formal da contribuição sindical compulsória, e sua consequente não recepção pela Constituição da República Federativa do Brasil, sem que, com isso, pretenda-se reavivar a malfadada Lei le Chapelier, de 1791, que proibira todas as associações operárias e patronais, mas sim fomentar um questionamento quanto ao custeio do atual sistema sindical. 
CARRA, César Augusto. Considerações sobre a constitucionalidade da contribuição sindical compulsória. Revista Eletrônica Direito e Política, Programa de Pós-Graduação Stricto Sensu em Ciência Jurídica da UNIVALI, Itajaí, v.10, n.2, 10 quadrimestre de 2015. Disponível em: www.univali.br/direitoepolitica - ISSN 1980-7791.

\section{1. ÂMBITO DOGMÁTICO DO ARTIGO}

Fixados os prolegômenos da presente dissertação, para fins de entendimento e exata compreensão do que será aqui abordado, deve-se frisar que não se indagará sobre a constitucionalidade material da contribuição sindical que, por constar expressamente do atual texto da Constituição da República de 1988 (arts. $8^{\circ}, \mathrm{V}$ e 149 ), é considerada pressuposta.

Assim, este artigo não enfrentará a contribuição sindical compulsória sob a vertente de sua constitucionalidade material, mas sim, sobre a suposta inconstitucionalidade formal do diploma instituidor da referida exação, utilizando, como parâmetro, a outrora vigente Constituição de 1937.

\section{ORIGEM E CONSIDERAÇÕES SOBRE A CONTRIBUIÇÃO SINDICAL COMPULSÓRIA}

Principiando a finalidade visada por este arrazoado, identifica-se que a contribuição sindical compulsória (imposto sindical), em nosso direito posto, teve como base inicial o Decreto-lei $n^{\circ} 2.377$, de 8 de julho de 1940 que, editado pelo então Presidente da República Getúlio Vargas, dispôs sobre o pagamento e a arrecadação das contribuições devidas aos sindicatos pelos que participam das categorias econômicas ou profissionais representadas pelas referidas entidades, sendo que, em seu art. $1^{\circ}$ estava estabelecido que:

As contribuições devidas aos sindicatos pelos que participem das categorias econômicas ou profissionais representadas pelas referidas entidades, consoante as alíneas a do art. 38 e f do art. $3^{\circ}$ do decreto-lei no 1.402 , de 5 de julho de 1939, serão, sob a denominação de "imposto sindical", pagas e arrecadadas pela forma estabelecida neste decreto-lei.

Complementado, 0 art. $1^{\circ}$, pelo art. $2^{\circ}$ do mencionado diploma, restava consignado que o imposto sindical seria "devido, por todos aqueles que participarem de uma determinada categoria econômica ou profissional, em favor da associação profissional legalmente reconhecida como sindicato representativo da mesma categoria". 
CARRA, César Augusto. Considerações sobre a constitucionalidade da contribuição sindical compulsória. Revista Eletrônica Direito e Política, Programa de Pós-Graduação Stricto Sensu em Ciência Jurídica da UNIVALI, Itajaí, v.10, n.2, 10 quadrimestre de 2015. Disponível em: www.univali.br/direitoepolitica - ISSN 1980-7791.

Pago de uma só vez, anualmente, nos termos do Decreto-lei $n^{\circ} 2.377$, de 1940, o valor do imposto sindical era decomposto em três categorias, variando de acordo com a tabela prescrita pelo aventado decreto.

Não existindo margem de discricionariedade, o empregador, ante o comando inserto no art. $4^{\circ}$ do diploma suso transcrito, era compelido a efetuar o desconto do imposto na folha de pagamento do empregado, emergindo, daí, a condição de responsável tributário pelo pagamento da aludida exação.

Regulamentado, posteriormente, pelo Decreto-lei $n^{\circ} 4.598$, de 20 de agosto de 1942, o Decreto-lei $\mathrm{n}^{\circ}$ 2.377, de 1940, quedou incorporado pelo texto da Consolidação das Leis do Trabalho, aprovada pelo Decreto-lei $n^{\circ} 5.452$, de $1^{\circ}$ de maio de 1943 que, reunindo sistematicamente as disposições encartadas em ambos os decretos-leis, passou a cuidar integralmente do assunto, por replicação.

Denominada, inicialmente, imposto sindical, e somente alterada sua nomenclatura pelo Decreto-lei $n^{\circ} 27$, de 14 de novembro de 1966, ulteriormente ratificado pelo Decreto-lei $n^{\circ} 229$, de 28 de fevereiro de 1967, a contribuição sindical fruía de evidente natureza jurídico-tributária.

Produto da Era Vargas e do Estado Novo, a contribuição sindical (imposto sindical), era impregnada com o autoritarismo típico do citado regime, totalmente contrário aos ideais policitados, à época, por uma minoria não dominante.

Realizando interpretação histórica do contexto social em que foi editado o Decreto-lei $n^{\circ} 2.377$, de 1940, o mesmo se estendendo ao Decreto-lei $n^{\circ} 5.452$, de 1943, depreende-se que as instituições estavam literalmente esfarrapadas.

Aprovados sob a égide da Constituição dos Estados Unidos do Brasil, de 1937, momento em que vigorava no país o golpe de Estado empregado por Getúlio Vargas, nos idos de novembro do mesmo ano que, atentando contra a ordem constitucional, e repetindo o já observado durante a Primeira República por Marechal Deodoro da Fonseca, dissolvendo o Congresso Nacional, outorgou nova 
CARRA, César Augusto. Considerações sobre a constitucionalidade da contribuição sindical compulsória. Revista Eletrônica Direito e Política, Programa de Pós-Graduação Stricto Sensu em Ciência Jurídica da UNIVALI, Itajaí, v.10, n.2, $1^{0}$ quadrimestre de 2015. Disponível em: www.univali.br/direitoepolitica - ISSN 1980-7791.

Constituição (Constituição de 1937), na qual se verifica evidente autoritarismo de suas disposições.

Dissolvido, o Poder Legislativo, em 1937, e perdurando seu fechamento até o ano de 1945, Getúlio Vargas, durante este período, desprezando o dogma da tripartição dos poderes, concentrava em suas mãos as atribuições típicas tanto do Executivo, quanto do Legislativo, passando a exercer a atividade legiferante por meio dos chamados decretos-leis.

Arrogando-se, de acordo com o art. 37 da Carta Constitucional então vigente, como autoridade suprema do Estado, e pouco empolgado pela tese da supremacia da Constituição, mesmo frente às medidas previstas e executadas durante o Estado Novo, os atos emanados daquele governo, pelo menos segundo a visão constitucionalista de agora, deveriam conter a conformidade mínima com o texto constitucional, com pena de, assim não o fazendo, predicarem-se de inconstitucionais, pois, mesmo sendo a Constituição de 1937, na visão de Ferdinand Lassalle ${ }^{2}$, produto dos fatores reais de poder, retomando as lições de Konrad Hesse $^{3}$ e Hans Kelsen ${ }^{4}$, para situar-se como constituição, era indispensável a existência, ainda que ínfima, da força normativa e da supremacia desta; ou seja, a Constituição de 1937, no escólio de Pinto Ferreira, deveria ser como uma "pedra angular, em que assenta o edifício do moderno direito político" ${ }^{5}$, a fonte de onde promana a validade de todas as normas que lhe são inferiores.

Pontuada aquela questão, organizando a nação, a polaca, disciplinando algumas medidas a serem tomadas durante o estado de exceção, a Constituição da República estabeleceu em seu art. 13 o seguinte:

Art. 13. O Presidente da República, nos períodos de recesso do Parlamento ou de dissolução da Câmara dos Deputados,

\footnotetext{
${ }^{2}$ LASSALLE, Ferdinand. O que é uma constituição? Série Clássicos Cultura \& Leitura. São Paulo: Edijur, 2012.

${ }^{3}$ HESSE, Konrad. A força normativa da constituição. Porto Alegre: Sérgio Fabris, 1991.

${ }^{4}$ KELSEN, Hans. Teoria Pura do Direito. 6. ed. Coleção Textos Fundamentais. São Paulo: Revista dos Tribunais, 2009.
}

${ }^{5}$ FERREIRA, Pinto. Curso de direito constitucional. 9. ed. São Paulo: Saraiva, 1998, p. 90. 
CARRA, César Augusto. Considerações sobre a constitucionalidade da contribuição sindical compulsória. Revista Eletrônica Direito e Política, Programa de Pós-Graduação Stricto Sensu em Ciência Jurídica da UNIVALI, Itajaí, v.10, n.2, 10 quadrimestre de 2015. Disponível em: www.univali.br/direitoepolitica - ISSN 1980-7791.

poderá, se o exigirem as necessidades do Estado, expedir decretos-leis sobre as matérias de competência legislativa da União, excetuadas as seguintes:

a) modificações à Constituição;

b) legislação eleitoral;

c) orçamento;

d) impostos;

e) instituição de monopólios;

f) moeda;

g) empréstimos públicos;

h) alienação e oneração de bens imóveis da União.

Parágrafo único - Os decretos-leis para serem expedidos dependem de parecer do Conselho da Economia Nacional, nas matérias da sua competência consultiva.

Elencando vedações materiais à edição de decretos-leis, e inserindo dentre tais temas a matéria "impostos", configurada a situação de recesso do Parlamento, ou dissolução da Câmara dos Deputados, ao Presidente da República, de acordo com o mandamento constitucional, seria defeso dispor, via decreto-lei, de assuntos como impostos.

Limitando a atuação do Chefe do Executivo Federal, o art. 13 passou a ser fundamento seguro para se sustentar a inconstitucionalidade formal do Decretolei $\mathrm{n}^{\circ}$ 2.377, de 1940, e dos arts. 578 a 600 do Decreto-lei $n^{\circ}$ 5.452, de 1942.

Conquanto se possa sustentar tal situação, dúvidas poderiam emergir quanto eventual contradição entre o art. 13 e o art. 180 da Carta de 1937, isso porque, enquanto esse restringia o campo de ação dos decretos-lei, este determinava que "enquanto não se reunir o Parlamento nacional, o Presidente da República terá o poder de expedir decretos-leis sobre todas as matérias da competência legislativa da União".

Virtualmente díspares, caso não sejam objeto de interpretação sistêmica, e arroteada pelas proposições da unidade da constituição e da concordância 
CARRA, César Augusto. Considerações sobre a constitucionalidade da contribuição sindical compulsória. Revista Eletrônica Direito e Política, Programa de Pós-Graduação Stricto Sensu em Ciência Jurídica da UNIVALI, Itajaí, v.10, n.2, $1^{0}$ quadrimestre de 2015. Disponível em: www.univali.br/direitoepolitica - ISSN 1980-7791.

prática, ou da harmonização, os artigos em destaque poderiam, deveras, entrechocar-se.

Todavia, ambos os artigos se compatibilizam num ordenamento jurídico ideal, isso porque, tendo em mira o já assinalado princípio da concordância prática, o art. 180 da Constituição de 1937 - cuja redação foi elevada pelo Presidente da República como fundamento determinante da edição do ato (decreto-lei) -, não tinha a vocação de derrogar, ou momentaneamente afastar, a proibição clausulada no art. 13. Ou seja, ainda que previsto no art. 180 da Constituição de 1937 uma ampla liberdade de ação via decretos-leis, tal prerrogativa não poderia traspassar as vedações expressamente previstas nas alíneas do art. 13, pois, segundo o postulado do legislador racional, mediante um dos princípios da interpretação constitucional fixados por Konrad Hesse, qual seja, o princípio da concordância prática:

nos casos de conflito entre normas constitucionais, quando programas normativos de duas normas de igual valor se entrechocam, o critério recomenda que o alcance das normas seja comprimido até que se encontre o ponto de ajuste de cada qual segundo a importância que possuem no caso concreto. Se é esperado do intérprete que extraia o máximo efeito da norma constitucional, esse exercício pode vir a provocar choque com idêntica pretensão de outras normas constitucionais. Devem, então, ser conciliadas as pretensões de efetividade dessas normas, mediante 0 estabelecimento de limites ajustados aos casos concretos em que são chamados a incidir. ${ }^{6}$

\section{DA NATUREZA JURÍDICA DA CONTRIBUIÇÃO SINDICAL}

Verificada a complementariedade existente entre os preceptivos citados, remanesce apenas saber, a fim de se chegar a um juízo de provável inconstitucionalidade, se a matéria versada no Decreto-lei $n^{\circ} 2.377$, de 1940, posteriormente encampada nos arts. 578 a 600 do Decreto-lei $n^{\circ} 5.452$, de

\footnotetext{
${ }^{6}$ MENDES, Gilmar Ferreira; BRANCO, Paulo Gustavo Gonet. Curso de Direito Constitucional. 7. ed. São Paulo: Saraiva, 2012, p. 108.
} 
CARRA, César Augusto. Considerações sobre a constitucionalidade da contribuição sindical compulsória. Revista Eletrônica Direito e Política, Programa de Pós-Graduação Stricto Sensu em Ciência Jurídica da UNIVALI, Itajaí, v.10, n.2, $1^{0}$ quadrimestre de 2015. Disponível em: www.univali.br/direitoepolitica - ISSN 1980-7791.

1943, situava-se no enquadramento dogmático de imposto, colidindo, portanto, com o normando expressado no art. 13, d da Carta de 1937.

Objetivando solucionar a controvérsia instaurada, antes de sustentar a caracterização da dita exação como imposto, urge identificar a natureza jurídica do instituto em estudo.

Recorrendo a doutrina de Paulo de Barros Carvalho, evidencia-se que a contribuição sindical, diversa da contribuição confederativa descrita no $8^{\circ}, \mathrm{V}$ da Constituição da República, detém natureza jurídico-tributária, conforme expõe:

Não é de agora que advogamos a tese de que as chamadas contribuições sociais têm natureza tributária. Vimo-las sempre como figuras de impostos ou de taxas, em estrita consonância com o critério constitucional consubstanciado naquilo que nominamos de tipologia tributária no Brasil. Todo o suporte argumentativo calcava-se na orientação do sistema, visto e examinado na sua integridade estrutural. Assim, outra coisa não fez o legislador constituinte senão prescrever manifestamente que as contribuições sociais são entidades tributárias, subordinando-se em tudo e por tudo às linhas definitórias do regime constitucional peculiar dos tributos. ${ }^{7}$

Detendo, segundo Paulo de Barros Carvalho, feição tributária - como a própria nomenclatura já estava a indiciar - a natureza jurídica da contribuição sindical compulsória encetou grande discussão em doutrina ${ }^{8}$, predominando 0 entendimento de que, segundo a teoria fiscal, a contribuição seria considerada como um tributo ${ }^{9}$.

\footnotetext{
7 CARVALHO, Paulo de Barros. Curso de Direito Tributário. 26. ed. São Paulo: Saraiva, 2014, p. 42.

${ }^{8}$ No escólio de Marco Aurélio Greco, a contribuição sindical não pode ser considerada como tributo, isso porque o art. 149 determina que seja aplicada a disciplina típica do Direito Tributário; se manda aplicar as normas gerais de Direito Tributário, se impõe as limitações da legalidade, anterioridade e irretroatividade para as contribuições, é porque elas não estão dentro do âmbito tributário, não pertencem a esse gênero. Se estivessem, não precisaria mandar observar tais ou quais regras e critérios. (GRECO, Marco Aurélio. Contribuições: uma figura sui generis. São Paulo: Dialética, 2000, p.81).

9 Defendem a classificação da contribuição sindical como tributo, dentre outros, Roque Antônio Carraza e Sérgio Pinto Martins.
} 
CARRA, César Augusto. Considerações sobre a constitucionalidade da contribuição sindical compulsória. Revista Eletrônica Direito e Política, Programa de Pós-Graduação Stricto Sensu em Ciência Jurídica da UNIVALI, Itajaí, v.10, n.2, $1^{\circ}$ quadrimestre de 2015. Disponível em: www.univali.br/direitoepolitica - ISSN 1980-7791.

Justificada sua natureza jurídica, a doutrina passou a deblaterar se a contribuição seria considerada tributo de natureza autônoma ou classificável segundo uma das modalidades desse.

Pairando embate sobre o enquadramento como imposto ou contribuição especial, com pouca tecnicidade jurídica, e desprezando conceitos e métodos interpretativos fundamentais da hermenêutica, dentre os quais, o de que a norma tem que ser interpretada dentro do sistema no qual se enquadra, verificou-se despontar o entendimento de que a contribuição teria natureza jurídica de contribuição especial (contribuição de interesse das categorias profissionais), haja vista sua referibilidade indireta, destinando-se o produto de sua arrecadação a uma finalidade específica, qual seja, prover receitas às associações reconhecidas pelo Ministério do Trabalho e Emprego como sindicatos.

Postilhões dessa definição é o doutrinador Ricardo Lobo Torres ${ }^{10}$, dentre outros. Resguardadas as convicções dos afamados juristas, sob a ótica da hermenêutica, a conclusão por eles obtida se mostra questionável.

Interpretando a figura da contribuição sindical dentro do ordenamento jurídico hodierno, os citados jurisconsultos desprezaram acontecimentos significantes para alcançar a correta ilação sobre o assunto.

Necessitando acorrer ao sistema vigorante ao tempo da edição do diploma, para o acerto no enquadramento do instituto, numa visão muito mais simplista do que a defendida por Geraldo Ataliba ${ }^{11}$ e sua hipótese de incidência tributária, teriam

\footnotetext{
${ }^{10}$ A contribuição é um tertium genus de tributo, que se situa a meio passo entre o imposto e a taxa. Aproxima-se do imposto, porque os respectivos fatos geradores aperfeiçoam-se tão logo ocorra a situação descrita em lei, independentemente de qualquer manifestação de vontade do contribuinte; mas dele se extrema, porque o imposto não é contraprestacional nem se subordina ao princípio do custo/benefício, mas ao da capacidade contributiva. Assemelha-se à taxa porque ambas são remuneratórias de serviço público, refletem uma divisibilidade da vantagem ao contribuinte e se subordinam aos princípios do custo/benefício; dela se afasta, todavia, porque a taxa remunera a prestação de serviço público específico e divisível, enquanto a contribuição corresponde à atividade indivisível da administração. A contribuição é sempre especial, por ser forma contributiva que não se confunde com o imposto nem com a taxa. (TORRES, Ricardo Lobo. Curso de direito financeiro e tributário. 9. ed. Rio de Janeiro: Renovar, 2002. p. 365).
}

${ }^{11}$ ATALIBA, Geraldo. Hipótese de Incidência Tributária, a Informação de Que É. 6. ed. 12. Tiragem. São Paulo: Malheiros, 2004. 
CARRA, César Augusto. Considerações sobre a constitucionalidade da contribuição sindical compulsória. Revista Eletrônica Direito e Política, Programa de Pós-Graduação Stricto Sensu em Ciência Jurídica da UNIVALI, Itajaí, v.10, n.2, $1^{0}$ quadrimestre de 2015. Disponível em: www.univali.br/direitoepolitica - ISSN 1980-7791.

os doutrinadores que entender que, quando da criação do denominado imposto sindical, posteriormente tratado como contribuição sindical, o ordenamento jurídico brasileiro, ainda em fase incipiente, ressentia-se de um Código Tributário Nacional, que veio a existir apenas em 25 de outubro de 1966, com a promulgação da Lei ${ }^{\circ} 5.172$, nem mesmo com a visão tripartite ou pentapartite - inovação gerada pela atual Constituição - dos tributos.

Não concebendo as definições hoje existentes nos arts. $3^{\circ}, 4^{\circ}, 16$ e seguintes do CTN, nem as dos arts. 146, 149 e seguintes da Lei Fundamental, o enquadramento tributário, ao menos à época em que fora instituído o imposto sindical, gizando-se pela Constituição de 1937, e que apenas contemplava a classificação bipartida dos tributos, não diferençava outras espécies senão impostos ou taxas.

Desconhecendo a definição de tributos e de que seria irrelevante para a definição de sua natureza jurídica a denominação e demais características formais adotadas pela lei, ao referir-se o Decreto-lei $\mathrm{n}^{\circ} 2.377$, de 1940 , e pela mesma via os arts. 578 a 600 do Decreto-lei $n^{\circ}$ 5.452, de 1943, a imposto sindical, por óbvio estava a denotar a natureza jurídica deste.

Limitado em sua cognição, não seria crível entender que o Presidente da República, redigindo os Decretos-leis $n^{\circ}$ 2.377, de 1940 e 5.452, de 1943, instituindo o imposto sindical, estaria a designar tributo com a natureza de contribuição especial, pois essa, enquanto espécie tributária, não era sequer prevista pelo direito posto naquela ocasião. Por isso, a importância da utilização dos métodos de interpretação progressivo e histórico.

De acordo com o entendimento predominante, a melhor análise da natureza jurídica de um instituto deve ser feita segundo a lei, ou conjunto de leis, vigente ao tempo do ato (tempus regit actum). Por essa razão é que tentar desvendar a natureza jurídica da contribuição sindical à luz do ordenamento jurídico ora vigente, encerra séria distorção, ensejando vício no enquadramento.

Assim, predominando, à época, a divisão bipartite de tributos, é que se sustenta, para efeitos de controle de constitucionalidade, tratar-se a figura instituída pelo 
CARRA, César Augusto. Considerações sobre a constitucionalidade da contribuição sindical compulsória. Revista Eletrônica Direito e Política, Programa de Pós-Graduação Stricto Sensu em Ciência Jurídica da UNIVALI, Itajaí, v.10, n.2, 10 quadrimestre de 2015. Disponível em: www.univali.br/direitoepolitica - ISSN 1980-7791.

Decreto-lei $\mathrm{n}^{\circ}$ 2.377, de 1940, de nítido imposto, estando, neste ponto, concordes com Paulo de Barros Carvalho, para quem tal contribuição sempre se situou como imposto.

\section{DA INCONSTITUCIONALIDADE FORMAL DA CONTRIBUIÇÃO SINDICAL COMPULSÓRIA}

Justificada a natureza jurídica da referida exação, tem-se que não somente a definição da natureza jurídica deve ser feita aos olhos da legislação vigente à época de sua edição, como também a aferição de ser, ou não, a norma constitucional.

Jungida à Lei Fundamental em vigor ao tempo de sua publicação, é nesse momento que a lei infraconstitucional deve passar por um juízo de compatibilidade com o texto superior, nesse caso, a Constituição.

No específico desse artigo, por serem editados sob a égide da Carta Constitucional de 1937, é perante essa que os Decretos-leis $n^{\circ} 2.377$, de 1940 e 5.452, de 1943 (arts. 578 usque 600) devem ser analisados.

Iniciando o juízo de valor, demonstrado que a contribuição sindical, à luz do princípio do tempus regit actum, tem natureza tributária, classificando-se como nítido imposto, e verificado que ao tempo de sua decretação estava dissolvido o Parlamento Nacional, tem-se por perfectibilizada a atividade de subsunção do conceito do fato ao conceito da norma encartada no art. 13 da Constituição de 1937.

Importando contradição entre a normativa estabelecida na Carta Constitucional de 1937, e agregando-se a eficácia normativa, mesmo que mínima, daquele texto constitucional, não se vislumbra outra opção a não ser concluir pela inconstitucionalidade formal dos diplomas ora em estudo.

Exacerbando os limites preestabelecidos pelo art. 13 da polaca, o Decreto-lei $\mathrm{n}^{\circ}$ 2.377, de 1940, e os arts. 578 a 600 do Decreto-lei $n^{\circ} 5.452$, de 1943, foram 
CARRA, César Augusto. Considerações sobre a constitucionalidade da contribuição sindical compulsória. Revista Eletrônica Direito e Política, Programa de Pós-Graduação Stricto Sensu em Ciência Jurídica da UNIVALI, Itajaí, v.10, n.2, $1^{0}$ quadrimestre de 2015. Disponível em: www.univali.br/direitoepolitica - ISSN 1980-7791.

fulminados por vício de constitucionalidade formal, isso porque, delineada e observada a superveniência do evento previsto, recesso do Parlamento ou dissolução da Câmara dos Deputados, ao Presidente da República era vedado dispor sobre matéria de competência legislativa da União, como, v.g, impostos.

E a inconstitucionalidade não cessa por aí. Submetidos ao princípio da legalidade tributária, mesmo frente à Carta de 1937, os impostos, a teor do art. 49, estavam sujeitos a reserva de lei, ou seja, somente por lei em sentido estrito poderiam ser criados, majorados etc.

Desbordando dos lindes de sua competência, e reconhecido que, mesmo ante a disposição inserta no art. 187, a Constituição de 1937 teve vigor, sendo prova maior disso o controle de constitucionalidade exercido pelo Supremo Tribunal Federal durante esse período, cujas decisões foram posteriormente derrogadas pelo Decreto-lei $n^{\circ} 1.564$, de 05 de setembro de 1939, o Decreto-lei $n^{\circ} 2.377$, de 1940, e os arts. 578 a 600 do Decreto-lei $n^{\circ}$ 5.452, de 1943, padeceram, e ainda hoje padecem, de vício de constitucionalidade formal, entendido esse como os que traduzem defeito de formação do ato normativo.

Classificados por Vicente Raó ${ }^{12}$ como "normas de caráter secundário", os decretos-leis, pelo menos sob a ótica dos arts. 13, d e 49 da Carta de 1937, não poderiam ingressar na esfera da reserva legal, principalmente com carga inaugural.

A lei, de acordo com Geraldo Ataliba, "tem cunho inaugural, inovador - e o regulamento é ato menor, inferior, de aplicação. É ato secundário e, pois, meramente administrativo"13, englobado, portanto, na definição de legislação tributária. Por isso, é correta a declaração de inconstitucionalidade integral do Decreto-lei $n^{\circ} 2.377$, de 1940 , e dos arts. 578 a 600 do Decreto-lei $n^{\circ} 5.452$, de 1943.

12 RAÓ, Vicente. O Direito e a Vida dos Direitos. São Paulo: Resenha Universitária, 1976, p. 266.

${ }^{13}$ ATALIBA, Geraldo. República e Constituição. 2. ed. São Paulo: Malheiros, 2007, p. 33. 
CARRA, César Augusto. Considerações sobre a constitucionalidade da contribuição sindical compulsória. Revista Eletrônica Direito e Política, Programa de Pós-Graduação Stricto Sensu em Ciência Jurídica da UNIVALI, Itajaí, v.10, n.2, $1^{0}$ quadrimestre de 2015. Disponível em: www.univali.br/direitoepolitica - ISSN 1980-7791.

E nem há de se falar de que as disposições ulteriores - sejam constitucionais, sejam as estabelecidas pelos Decretos-leis $n^{\circ} 27$, de 1966, 229, de 1967, Leis $\mathrm{n}^{\circ}$ 6.386, de 09 de dezembro de 1976 e 11.648, de 31 de março de 2008 sanaram a pecha, pois, em se tratando de vício de constitucionalidade formal, inadmite-se a denominada sanatória.

O mesmo se pode dizer quanto à recepção do Decreto-lei $n^{\circ} 2.377$, de 1940, propugnada pelo eminente Ministro Sepúlveda Pertence que, conquanto não analisando o caso sob os fundamentos ora elevados, assentou, no RE 180.745/SP, Primeira Turma, DJ 24-03-1998, a recepção da contribuição sindical (imposto sindical) pela Constituição Federal de 1988. Acompanhe-se:

Sindicato: contribuição sindical da categoria: recepção. A recepção pela ordem constitucional vigente da contribuição sindical compulsória, prevista no art. 578 CLT e exigível de todos os integrantes da categoria, independentemente de sua filiação ao sindicato resulta do art. $8^{\circ}$, IV, in fine, da Constituição; não obsta à recepção a proclamação, no caput do art. $8^{\circ}$, do princípio da liberdade sindical, que há de ser compreendido a partir dos termos em que a Lei Fundamental a positivou, nos quais a unicidade (art. $8^{\circ}$, II) e a própria contribuição sindical de natureza tributária (art. $8^{\circ}$, IV) marcas características do modelo corporativista resistente -, dão a medida da sua relatividade (cf. MI 144, Pertence, RTJ 147/868, 874); nem impede a recepção questionada a falta da lei complementar prevista no art. 146, III, CF, à qual alude o art. 149, à vista do disposto no art. $34, \S \S 33^{\circ}$ e 40, das Disposições Transitórias (cf. RE 146733, Moreira Alves, RTJ $146 / 684,694){ }^{14}$

Em que pese aquela conclusão, sustenta-se a não recepção, e aqui sagra-se verdadeira hipótese de distinguish, pois, ainda que materialmente compatível com a Lei Fundamental de agora, veja o art. 149, sendo a dita exação inconstitucional do ponto de vista formal, é ela considerada nula desde sua instituição, ou seja, ab initio.

\footnotetext{
14 BRASIL. Supremo Tribunal Federal. Recurso Extraordinário $\mathbf{n}^{\circ} \mathbf{1 8 0 . 7 4 5 - S P}$. Sindicato: contribuição sindical da categoria: recepção. Recorrente: Décimo Sexto Cartório de Notas da Capital. Recorrido: Sindicato dos Escreventes e Auxiliares Notariais e Registrais do Estado de São Paulo Relator: Ministro Sepúlveda Pertence. Brasília, DF, 24 mar. 1998. Disponível em: <http://www.stf.jus.br/portal/jurisprudencia/listarJurisprudencia.asp?s1=\%28180745\%2ENUME\% 2E+OU+180745\%2EACMS\%2E\%29\&base=baseAcordaos\&url=http://tinyurl.com/b2azr9g >. Acesso em: 28 maio 2014.
} 
CARRA, César Augusto. Considerações sobre a constitucionalidade da contribuição sindical compulsória. Revista Eletrônica Direito e Política, Programa de Pós-Graduação Stricto Sensu em Ciência Jurídica da UNIVALI, Itajaí, v.10, n.2, 10 quadrimestre de 2015. Disponível em: www.univali.br/direitoepolitica - ISSN 1980-7791.

Assim, agregando-se ao raciocínio o dissertado por Gilmar Ferreira Mendes e Paulo Gustavo Gonet Branco:

uma vez que vigora o princípio de que, em tese, a inconstitucionalidade gera a nulidade - absoluta - da lei, uma norma na situação em tela já era nula desde quando editada, pouco importando a compatibilidade material com a nova Constituição, que não revigora diplomas nulos. ${ }^{15}$

A Constituição de 1988, ainda que conservando determinados efeitos, bem como a vigência da legislação pretérita, estabilizando nosso quadro institucional, tratou de insculpir, no art. 25, $\mathrm{I}^{16}$ de seu Ato das Disposições Constitucionais Transitórias, hipótese de recepção.

Por mais que prevista a recepção em determinados casos, subtraindo a competência conferida pelos diplomas anteriores ao Executivo, a Lei Fundamental revitalizou a primazia do Legislativo como forma de assegurar o ideal democrático, em que o povo governa o próprio povo.

Dessa forma, além de usurpar competência do Congresso Nacional, o Decreto-lei $n^{\circ}$ 2.377, de 1940, e os arts. 578 a 600 do Decreto-lei $n^{\circ}$ 5.452, de 1943, por mostrarem-se formalmente inconstitucionais, não foram recepcionados pela nova Constituição, quedando obstaculizados pela redação do art. 25 do ADCT.

Por oportuno, é mister citar o precedente formado pelo Supremo Tribunal Federal quando do julgamento do RE 272.872/RS, rel. Min. Ilmar Galvão, julgamento, DJ 10-10-2003, replicado no RE 435.278-AgR, rel. Min. Ricardo Lewandowski, DJE de 20-3-2012, no qual ficou assentado que:

O art. 25 do ADCT revogou todas as delegações de competência outorgadas ao Executivo, sobre a matéria reservada ao Congresso Nacional, mas não impediu a recepção dos diplomas legais legitimamente elaborados na

15 MENDES, Gilmar Ferreira; BRANCO, Paulo Gustavo Gonet. Curso de Direito Constitucional. 7. ed. São Paulo: Saraiva, 2012, p. 123.

16 Art. 25. Ficam revogados, a partir de cento e oitenta dias da promulgação da Constituição, sujeito este prazo a prorrogação por lei, todos os dispositivos legais que atribuam ou deleguem a órgão do Poder Executivo competência assinalada pela Constituição ao Congresso Nacional, especialmente no que tange a:

I - ação normativa; 
CARRA, César Augusto. Considerações sobre a constitucionalidade da contribuição sindical compulsória. Revista Eletrônica Direito e Política, Programa de Pós-Graduação Stricto Sensu em Ciência Jurídica da UNIVALI, Itajaí, v.10, n.2, $1^{0}$ quadrimestre de 2015. Disponível em: www.univali.br/direitoepolitica - ISSN 1980-7791.

vigência da Constituição anterior, desde que materialmente compatíveis com a nova Carta. ${ }^{17}$

Nesse diapasão, e devendo o decidido pelo Supremo Tribunal Federal no RE 272.872/RS, rel. Min. Ilmar Galvão ser compreendido mutatis mutandis, pela análise conjugada do art. 25 do ADCT com as decisões citadas, e o que mais foi dissertado nesse artigo, depreende-se que, por não haver sido legitimamente elaborado sob a vigência da Constituição de 1937, e despojando o Congresso Nacional de uma competência que lhe fora atribuída pelo texto constitucional, o Decreto-lei 2.377, de 1940 e os arts. 578 a 600 do Decreto-lei $n^{\circ}$ 5.452, de 1943, devem ser alijados da sistemática jurídica, reconhecendo sua não recepção pela ordem constitucional hodierna, haja vista o vício insanável na formação do ato, qual seja, erro de forma.

Assim, padecendo de vício de forma, vindo a lume através do veículo introdutor incorreto, a contribuição sindical, antigo imposto sindical, mostra-se formalmente inconstitucional, isso porque são inobservados os normandos expressamente estabelecidos no art. 13, d e art. 49 da Constituição de 1937.

Independentemente do momento político - democrático, czarista ou ditatorial do qual o Decreto-lei $n^{\circ} 2.377$, de 1940, e os arts. 578 a 600 do Decreto-lei $n^{\circ}$ 5.452, de 1943 provieram, o Presidente da República, caso pretendesse dispor sobre a matéria "imposto", deveria tê-lo feito por meio de lei ou, caso preciso, mediante autorização do Parlamento Nacional na forma disciplinada pelo art. 12 da polaca, o que não se observou.

Utilizando indevidamente uma prerrogativa sua, o Chefe do Executivo, transbordando os limites de sua competência, interpretou erroneamente sua própria Constituição, sendo que o art. 180 da Constituição de 1937 deve ser aplicado em consonância com o disposto no art. 13 do mesmo diploma.

17 BRASIL. Supremo Tribunal Federal. Recurso Extraordinário $\mathbf{n}^{\circ}$ 272.872-RS. Constitucional. Tributário. Salário-educação. Constitucionalidade. Recepção. Recorrente: Arvel Comércio de Veículos Ltda. Recorrido: Instituto Nacional do Seguro Social. Relator: Ministro Ilmar Galvão. Brasília, DF, 4 abril $2001 . \quad$ Disponível em: <http://www.stf.jus.br/portal/jurisprudencia/listarJurisprudencia.asp?s1=\%28272872\%2ENUME\% 2E+OU+272872\%2EACMS\%2E\%29\&base=baseAcordaos\&url=http://tinyurl.com/p5yhemc > . Acesso em: 28 maio 2014. 
CARRA, César Augusto. Considerações sobre a constitucionalidade da contribuição sindical compulsória. Revista Eletrônica Direito e Política, Programa de Pós-Graduação Stricto Sensu em Ciência Jurídica da UNIVALI, Itajaí, v.10, n.2, $1^{0}$ quadrimestre de 2015. Disponível em: www.univali.br/direitoepolitica - ISSN 1980-7791.

E nem se diga que o controle de constitucionalidade com base naqueles parâmetros (arts. 13, d e 149 da Constituição de 1937) estaria obstaculizado dada a ab-rogação daquela pelos textos constitucionais posteriores.

Para a compreensão do aqui tratado, não se deve desprezar a formação estabelecida pela Constituição de 1937, isso porque, em se tratando de controle de constitucionalidade sobre a via difusa, a jurisprudência é uníssona ao afirmar que o parâmetro de controle deverá ser a Constituição sob qual império foi editada a lei. Isso significa dizer, em matéria de controle de constitucionalidade incidental, que vigora, igualmente, o princípio tempus regit actum.

Analisando a doutrina de Gilmar Ferreira Mendes e Paulo Gustavo Gonet Branco, identifica-se que, conforme já preconizado, o controle de constitucionalidade de lei deve ter como parâmetro a Constituição em face da qual foi editada, pois:

de modo diverso do que se verifica com o controle abstrato de normas, que tem como parâmetro de controle a Constituição vigente, o controle incidental realiza-se em face da Constituição sob cujo império foi editada a lei ou ato normativa. ${ }^{18}$

E tão certo é esse entendimento que o próprio Supremo Tribunal Federal, no julgamento do RE 148.754/RJ, rel. Min. Francisco Rezek, DJ de 4-3-1994, assentou que a constitucionalidade das normas jurídicas que foram promulgadas antes da entrada em vigor da Constituição de 1988 deve ser aferida, na via de controle difuso, de acordo com a Constituição vigente à sua época.

Promulgados sob a égide da Constituição de 1937, a constitucionalidade do Decreto-lei $\mathrm{n}^{\circ}$ 2.377, de 1940 e dos arts. 578 a 600 da CLT, deverá ser analisada sob o crivo daquela Carta.

Com efeito, pouco importa, para o controle de constitucionalidade na via difusa, a existência da norma estampada no art. 149 da atual Constituição, e que autoriza a instituição de contribuição social de interesse das categorias

18 MENDES, Gilmar Ferreira; BRANCO, Paulo Gustavo Gonet. Curso de Direito Constitucional. 7. ed. São Paulo: Saraiva, 2012, p. 1181. 
CARRA, César Augusto. Considerações sobre a constitucionalidade da contribuição sindical compulsória. Revista Eletrônica Direito e Política, Programa de Pós-Graduação Stricto Sensu em Ciência Jurídica da UNIVALI, Itajaí, v.10, n.2, $1^{0}$ quadrimestre de 2015. Disponível em: www.univali.br/direitoepolitica - ISSN 1980-7791.

profissionais, porque a constitucionalidade ou inconstitucionalidade do imposto sindical deve ser enfrentada tendo por base o texto constitucional de 1937.

\section{CONSIDERAÇÕES FINAIS}

À guisa da conclusão, consegue-se aferir que, a despeito de poder vir a ser sustentada sua compatibilidade material com a vigente Constituição, existindo, inclusive, precedente do Supremo Tribunal Federal, devendo ser o instituto interpretado segundo a lei vigente à época de sua edição, a contribuição sindical, instituída inicialmente pelo Decreto-lei $\mathrm{n}^{\circ}$ 2.377, de 1940, posteriormente replicada pelos arts. 578 a 600 do Decreto-lei $n^{\circ}$ 5.452, de 1943, predicando-se como nítido imposto, não poderia, nos termos do preconizado art. $13, d$ da Constituição de 1937, ter sido introduzida no ordenamento jurídico brasileiro por meio de decreto-lei.

Submetida, a matéria "imposto", ao princípio da legalidade tributária (art. 49), somente por lei poderia o Presidente da República regular tal questão, não servindo de argumento para alterar tal proceder o fato de estar dissolvido o Parlamento Nacional ou a Câmara dos Deputados, isso porque, conquanto constatada tal situação, merecendo compatibilização, aquela temática estaria arrebatada da capacidade de disposição do Chefe do Executivo, conforme análise sistemática do art. 13, d com o art. 180.

Isso significa dizer que, ainda que pudesse dispor sobre todas as matérias da União, durante a não reunião ou dissolução do Parlamento, tal faculdade estaria parcialmente restringida, isso porque foi expressamente vedada a edição de decretos-leis sobre impostos.

De fato, impedido de versar sobre impostos, uma vez incidindo em tal situação, conclusão inarredável será o reconhecimento da inconstitucionalidade formal do chamado imposto sindical, atual contribuição sindical, pois advindo em dissintonia com a Constituição da República. 
CARRA, César Augusto. Considerações sobre a constitucionalidade da contribuição sindical compulsória. Revista Eletrônica Direito e Política, Programa de Pós-Graduação Stricto Sensu em Ciência Jurídica da UNIVALI, Itajaí, v.10, n.2, $1^{0}$ quadrimestre de 2015. Disponível em: www.univali.br/direitoepolitica - ISSN 1980-7791.

Erigindo-se no modelo piramidal, e grassando aceitação o princípio da supremacia da Constituição, o Decreto-lei $n^{\circ} 2.377$, de 1940 e os arts. 578 a 600 do Decreto-lei $n^{\circ}$ 5.452, de 1943, situando-se no âmbito da legislação infraconstitucional, não poderiam contrariar o texto que lhes fosse juridicamente superior, sob pena de virem a ser declarados inválidos, o que de fato ocorreu.

Assim, tornando-se inválidos, e não se prestando o poder constituinte originário a restabelecer diplomas nulos, a recepção da contribuição sindical não poderia ter sido reconhecida, motivo pelo qual se tem como revogada pela nova ordem constitucional, inviabilizando, assim, sua cobrança por parte das entidades sindicais.

\section{REFERÊNCIAS DAS FONTES CITADAS}

ATALIBA, Geraldo. República e Constituição. 2. ed. São Paulo: Malheiros, 2007.

ATALIBA, Geraldo. Hipótese de Incidência Tributária, a Informação de Que É. 6. ed. São Paulo: Malheiros, 2004.

BRASIL. Constituição (1937). Constituição dos Estados Unidos do Brasil, Rio de Janeiro, RJ, 10 nov. 1937. Disponível em <http://www.planalto.gov.br/ccivil_03/constituicao/constituicao37.htm>. Acesso em: 23 maio 2014

BRASIL. Decreto-lei $n^{\circ} 2.377$, de 8 de julho de 1940. Dispõe sobre o pagamento e a arrecadação das contribuições devidas aos sindicatos pelos que participam das categorias econômicas ou profissionais representadas pelas referidas entidades. Diário Oficial [da] República Federativa do Brasil, Rio de Janeiro, RJ, 10 jul. $1940 . \quad$ Disponível em: <http://www2.camara.leg.br/legin/fed/declei/1940-1949/decreto-lei-2377-8julho-1940-412315-publicacaooriginal-1-pe.html>. Acesso em: 5 jun. 2014.

BRASIL. Decreto-lei $n^{\circ} 5.452$, de $1^{\circ}$ de maio de 1943. Aprova a Consolidação das Leis do Trabalho. Diário Oficial [da] República Federativa do Brasil, Rio de Janeiro, RJ, 9 ago. 1943. Disponível em: <http://www.planalto.gov.br/ccivil_03/decreto-lei/del5452.htm>. Acesso em: 6 jun. 2014.

BRASIL. Constituição (1988). Constituição da República Federativa do Brasil. 40. ed. São Paulo: Saraiva, 2007. 
CARRA, César Augusto. Considerações sobre a constitucionalidade da contribuição sindical compulsória. Revista Eletrônica Direito e Política, Programa de Pós-Graduação Stricto Sensu em Ciência Jurídica da UNIVALI, Itajaí, v.10, n.2, 10 quadrimestre de 2015. Disponível em: www.univali.br/direitoepolitica - ISSN 1980-7791.

BRASIL. Supremo Tribunal Federal. Recurso Extraordinário $\mathbf{n}^{\circ}$ 148.754-RJ. Constitucional. Art. 55-II da Carta anterior. Contribuição para o PIS. Decretosleis 2.445 e 2.449, de 1988. Inconstitucionalidade. Recorrente: Itaparica Empreendimentos e Participações S/A e outros. Recorrido: União Federal. Relator: Ministro Francisco Rezek. Brasília, DF, 24 jun. 1993. Disponível em: <http://www.stf.jus.br/portal/jurisprudencia/listarJurisprudencia.asp?s1=\%2814 $8754 \% 2 E N U M E \% 2 E+O U+148754 \% 2 E A C M S \% 2 E \% 29 \&$ base=baseAcordaos\&url= http://tinyurl.com/a3qyzyz>. Acesso em: 28 maio 2014.

BRASIL. Supremo Tribunal Federal. Recurso Extraordinário $\mathbf{n}^{\circ}$ 180.745-SP. Sindicato. Contribuição sindical da categoria. Recepção. Recorrente: Décimo Sexto Cartório de Notas da Capital. Recorrido: Sindicato dos Escreventes e Auxiliares Notariais e Registrais do Estado de São Paulo. Relator: Ministro Sepúlveda Pertence. Brasília, DF, 24 mar. 1998. Disponível em: <http://www.stf.jus.br/portal/jurisprudencia/listarJurisprudencia.asp?s1=\%2818 0745\%2ENUME\%2E+OU+180745\%2EACMS\%2E\%29\&base=baseAcordaos\&url= http://tinyurl.com/b2azr9g>. Acesso em: 28 maio 2014.

BRASIL. Supremo Tribunal Federal. Recurso Extraordinário $\mathbf{n}^{\circ}$ 272.872-RS. Constitucional. Tributário. Salário-educação. Constitucionalidade. Recepção. Recorrente: Arvel Comércio de Veículos Ltda. Recorrido: Instituto Nacional do Seguro Social. Relator: Ministro Ilmar Galvão. Brasília, DF, 4 abril 2001. Disponível em: <http://www.stf.jus.br/portal/jurisprudencia/listarJurisprudencia.asp?s1=\%2827 $2872 \% 2 \mathrm{ENUME} \% 2 \mathrm{E}+\mathrm{OU}+272872 \% 2 \mathrm{EACMS} \% 2 \mathrm{E} \% 29 \&$ base=baseAcordaos\&url= http://tinyurl.com/p5yhemc>. Acesso em: 28 maio 2014.

BRASIL. Supremo Tribunal Federal. Agravo Regimental no Recurso Extraordinário $n^{\circ}$ 435.278-RS. Agravo regimental no recurso extraordinário. tributário. Selo de controle do imposto sobre produtos industrializados. Ressarcimento. Estipulação dos critérios de cobrança pelo Ministro da Fazenda. Art. $3^{\circ}$ do Decreto Lei 1.347/1975. Insubsistência da delegação após o advento da nova ordem constitucional. Art. 25 do ADCT. Possibilidade de cobrança com fundamento nos atos normativos editados em momento anterior ao prazo fixado no art. 25 do ADCT. Agravo improvido. Agravante: União. Agravado: Multidrink Indústria de Bebidas Ltda. Relator: Ministro Ricardo Lewandowski. Brasília, DF, 6 mar. $2012 . \quad$ Disponível em: <http://www.stf.jus.br/portal/jurisprudencia/listarJurisprudencia.asp?s1=\%2843 $5278 \% 2 \mathrm{ENUME} \% 2 \mathrm{E}+\mathrm{OU}+435278 \% 2 \mathrm{EACMS} \% 2 \mathrm{E} \% 29 \&$ base=baseAcordaos\&url= http://tinyurl.com/beb3vqb>. Acesso em: 28 maio 2014.

CARRAZA, Roque Antônio. Curso de direito constitucional tributário. 3. ed. São Paulo: Revista dos Tribunais, 1991.

CARVALHO, Paulo de Barros. Curso de Direito Tributário. 26. ed. São Paulo: Saraiva, 2014.

GRECO, Marco Aurélio. Contribuições: uma figura sui generis. São Paulo: Dialética, 2000. 
CARRA, César Augusto. Considerações sobre a constitucionalidade da contribuição sindical compulsória. Revista Eletrônica Direito e Política, Programa de Pós-Graduação Stricto Sensu em Ciência Jurídica da UNIVALI, Itajaí, v.10, n.2, $1^{\circ}$ quadrimestre de 2015. Disponível em: www.univali.br/direitoepolitica - ISSN 1980-7791.

HESSE, Konrad. A força normativa da constituição. Porto Alegre: Sérgio Fabris, 1991.

FERREIRA, Pinto. Curso de direito constitucional. 9. ed. São Paulo: Saraiva, 1998.

KELSEN, Hans. Teoria Pura do Direito. 6. ed. Coleção Textos Fundamentais. São Paulo: Revista dos Tribunais, 2009.

LASSALE, Ferdinand. O que é uma constituição? São Paulo: Edijur, 2012.

MARTINS, Sérgio Pinto. Contribuições sindicais: direito comparado e internacional; contribuições assistencial, confederativa e sindical. 3. ed. São Paulo: Atlas, 2001.

MENDES, Gilmar Ferreira; BRANCO, Paulo Gustavo Gonet. Curso de Direito Constitucional. 7. ed. São Paulo: Saraiva, 2012.

RAÓ, Vicente. O Direito e a Vida dos Direitos. São Paulo: Resenha Universitária, 1976.

TORRES, Ricardo Lobo. Curso de direito financeiro e tributário. 9. ed. Rio de Janeiro: Renovar, 2002.

Submetido em: Fevereiro/2015

Aprovado em: Março/2015 